\title{
Фотоприемные модули на основе ГЭС КРТ МЛЭ для спектральных диапазонов 1-3, 3-5, 8-10 мкм форматом до 2000×2000 элементов
}

Ю.Г. Сидоров, И.В. Сабинина, Г.Ю. Сидоров, Д.В. Марин, В.В. Васильев, М.В. Якушев, Ю.С. Макаров, А.В. Зверев, И.В. Марчишин, А.В. Предеин, В.С. Варавин, С.А. Дворецкий, А.В. Вишняков, В.Г. Ремесник, Д.В. Горшков, А.В.Латышев

Институт физики полупроводников им. А.В. Ржанова СО РАН, Новосибирск, 630090, пр. Ак. Лаврентьева, 13

тел: (383)330-89-60, ракс: (383)333-27-71, эл.nочта: george@isp.nsc.ru

DOI 10.34077/RCSP2019-52

Материал кадмий-ртуть-теллур является наиболее привлекательным для изготовления охлаждаемых гибридных фотоприемных модулей чувствительных в разных диапазонах ИК-спектра $[1,2,3]$. Благодаря преимуществам метода молекулярно лучевой эпитаксии (МЛЭ) стало возможным изготовление материала приборного качества на несогласованных подложках, таких как GaAs и Si. Помимо ценовых преимуществ, применение Si подложек позволяет устранить термомеханические напряжения ограничивающие размеры охлаждаемых гибридных ФПМ и их ресурс.

Ряд усовершенствований технологии изготовления ГЭС КРТ МЛЭ и фоточувствительных модулей на их основе сделанных в ИФП СО РАН за последние годы позволил в значительной степени улучшить их параметры, вплотную приблизившись к импортным аналогам. Среди таких усовершенствований можно выделить улучшенную архитектуру слоев КРТ, обеспечивающую повышенную однородность рабочих смещений на диодах и встроенный коротковолновый фильтр. Достигнутое качество ГЭС КРТ на подложках из кремния позволяет использовать его для всех изготавливаемых ФПМ.

Проведены экспериментальные исследования в части разработки фотоприемников с повышенной рабочей температурой. Для этого была отработана технология изготовления p-на-n диодов для диапазона 1-3 мкм, в целях повешения рабочей температуры приемника до 170К. Также была повышена рабочая температура диодов n-на-р в диапазоне 3-5 мкм до 110-120К.

Разработана быстродействующая кремниевая схема считывания формата 384x288, обеспечивающая полнокадровую частоту до 680Гц, с еще большей частотой в режиме «окна».

При изготовлении матриц диодов было внедрено меза-травление, позволяющее изолировать соседние диоды, новое диэлектрическое покрытие, обеспечивающее более высокую однородность свойств границы раздела, а за счет совершенствования технологий фотолитографии были получены матрицы большой площади (до $4 \mathrm{x} 4$ см) и уменьшенным до 20 мкм шагом.

Технология гибридной сборки матрицы диодов и кремниевой схемы считывания также была существенно доработана, в частности повышена точность планаризации совмещаемых кристаллов, в результате чего стала возможной гибридизация ФПМ форматом $2000 \times 2000$ элементов с шагом 20 мкм. Выполнена работа по разработке архитектуры и технологии гибридизации ФПМ формата $1500 \times 1500$ элементов пригодных для мозаичной стыковки с зазором между модулями менее 120 мкм для изготовления ФПУ формата $3000 \times 3000$ элементов. Приведены параметры ФПМ форматов $4 \times 288$, $320 \times 256,384 \times 288,640 \times 512,1024 \times 1024,1500 \times 1500$ и $2000 \times 2000$ изготовленных на основе ГЭС КРТ МЛЭ на подложках из кремния.

Работа по разработке мегапиксельных фотоприемников выполнена совместно с НПО Восток и лабораторией №14 ИФП СО РАН: А.П. Ковчавцев, В.М. Базовкин, В.Г. Половинкин, А.А. Гузев, А.В. Царенко

\section{Лuтература}

[1] Fossum E., Pain B. Infrared readout electronics for space-science sensors: state of art and future directions // Proc. SPIE. 1994. No 2020. P. 262.

[2] Tribolet Ph., Hirel Ph., Lussereau A., Vuillermet M. Main results of sofradir IRFPAs including IRCCD and IRCMOS detectors // Proc. SPIE. 1994. No 2252. P. 369.

[3] Рогальский А. Инфракрасные детекторы.- Пер. с англ. /Под ред. А.В. Войцеховского. Новосибирск: Наука, 2003. 